\title{
Erosion Effect on Soil Physical Properties in Selected Farmlands in Gidan Kwano, Niger State
}

\author{
Abdulkadir Abdullahi \\ Department of Agricultural and Bio Resources Engineering, Federal University of Technology, \\ PMB 65, Minna, Niger State, Nigeria.
}

abdullahiabdulkadir53@gmail.com

Keywords: soil physical properties, erosion effect, soil properties

\begin{abstract}
The study was conducted to investigate if erosion is a major problem and to identify the effect of erosion on some physical properties on selected farmlands on four farms in Gidan kwano. It was done by observation, interview, and questionnaire and soil sample analysis. The infiltration rate, bulk density, porosity, organic matter content, particle size and aggregate stability were determined for all the sample location. The erosion fields results were compared with the results of the non-eroded fields. The results showed that farming was done with simple method and mechanized equipment when available and erosion was considered a major problem in all the farms. The results revealed that bulk density values ranged between $1.475 \mathrm{gcm}^{-3}$ and $1.606 \mathrm{gcm}^{-3}$, cumulative infiltration rate fluctuated between $29.75 \mathrm{~cm} / \mathrm{hr}$ and $37.48 \mathrm{~cm} / \mathrm{hr}$, porosity ranged between $36.49 \%$ and $44.34 \%$, organic matter content fluctuated between $0.29 \%$ and $0.73 \%$ and aggregate stability ranged between $58.00 \%$ and $67.60 \%$ for the erosion field. The results also revealed that bulk density fluctuated between $1.458 \mathrm{gcm}^{-3}$ and $1.544 \mathrm{gcm}^{-3}$, cumulative infiltration rate ranged between $32.19 \mathrm{~cm} / \mathrm{hr}$ and $40.48 \mathrm{~cm} / \mathrm{hr}$, porosity fluctuated between $41.73 \%$ and $44.98 \%$, organic matter content ranged between $0.30 \%$ and $1.09 \%$ and aggregate stability ranged between $63.97 \%$ and $68.93 \%$ for the non-eroded field. From the results, it provides evidence that the effects of erosion on the physical properties were increased bulk density, decreased infiltration rate, organic matter content, porosity, aggregate stability and percentage sand, silt and clay content. Statistical analysis proved that the results were significant $(\mathrm{p}<0.05)$ except for the bulk density and porosity which could be attributed to the swelling and compaction characteristics of the soils.
\end{abstract}

\section{Introduction}

Soil is a valuable natural resource that aids the production of crops and food product [1]. The aptness of soil for crop production is dependent on the quality of the soil's physical, chemical and biological properties [1]. One of the naturally occurring processes that affect detrimentally these soil properties and subsequent crop production is soil erosion [2]. Physical properties such as bulk density, infiltration rate, and organic matter content, aggregate stability and soil texture has great effect on the rate of erosion [3]. Farming activities all over the world are made difficult due to the uprising hazard of erosion.

Farmers in Gidan kwano are not left out. Overtime, erosion has gradually become a problem in this area as farmers are now facing challenges due to reduced yield and low productivity when compared to previous years. Hence, the need to analyze erosion effects on some properties of the soils in Gidan kwano farmlands is vitally important. Identifying what entail farming in the area would be of paramount importance as it would provide the appropriate direction in the course of the work and also offer vital and supportive information. The aim of this study was to determine and analyze the effect of erosion on some physical properties in some farms in Gidan kwano. Soil erosion rate is largely dependent on properties of the soil. Therefore, there is a need to determine the effect of soil erosion on the physical properties so as to know the physical properties and factors that aids or deter erosion so that erosion could be checked effectively in Gidan kwano. 


\section{Theory}

Soil properties are inherent characteristics and qualities of soil [4]. Soil properties generally influence the nature of crops that grow on a soil or species of plants that grows in any locality [5]. Soil properties influences many processes in the soil to make it suitable for agricultural practices and other purposes [6]. Structure, texture, and porosity influence the movement and retention of water, solutes and air in the soil, which subsequently affect organism activities and plant growth [1]. Physical properties of soils may almost be permanent properties unless modified and changed by farming and environmental activities such as shifting cultivation, harvesting operations, forest fires and tillage [6]. Important physical properties of soils include texture, structure, porosity, density, aeration, temperature, water retention, and infiltration rate which is determined by the ease of root penetration, the water availability and the rate of water absorption by plants, the amount and quantity of oxygen and other gases in the soil and the degree to which water moves both vertically and laterally through the soil [7]. Rosen (2009) [8] argued that soils can be degraded because of erosion, but already degraded soils have a higher erosion risk. It was stated that it is therefore difficult to identify the primary causes. It was further explained that erosion causes reduction in infiltration and water-storage capacity, nutrient and organic matter content, soil depth, productivity, vegetation growth and biodiversity. These factors are inter-related and it is very arduous to separate the relative impact and effect one has from the other. Erosion effect on soils is dependent on soil intrinsic properties, the sorting and transport capacity of the erosive agent, the relationship with soil management practices, climate and the slope [9].

\section{Material and Methodology}

Materials used during this study includes questionnaires, GPS, soil auger, stop watch, mallet, infiltrometer rings, wooden plank, core rings, cheese cloths, oven, muffle furnace, measuring cylinders, thermometer, hydrometer, stirrer, crucibles, evaporating dish, containers, sodium hexametaphosphate, distilled water, wash bottle, motor shaker, cans, textural chart, meter rule and record book. The study was focused on Gidan Kwano village which is about $13.4 \mathrm{~km}$ from central Minna. It lies within the coordinates $9^{\circ} 32^{\prime} 27.01^{\prime \prime} \mathrm{N}$ and $6^{\circ} 28^{\prime} 31.59^{\prime \prime} \mathrm{E}, 9^{\circ} 32^{\prime} 27.02^{\prime \prime} \mathrm{N}$ and $6^{\circ}$ 28'29.39' $\mathrm{\prime}$, 9 $9^{\circ} 31^{\prime} 58.21^{\prime \prime} \mathrm{N}$ and $6^{\circ} 28^{\prime} 05.27^{\prime} \mathrm{E}, 9^{\circ} 32^{\prime} 02.39^{\prime \prime} \mathrm{N}$ and $6^{\circ} 28^{\prime} 27.03^{\prime \prime} \mathrm{E}$. Climate of Minna is sub-humid with mean annual rainfall of about $1284 \mathrm{~mm}$ and a distinct dry season of about 5 months duration occurring from November to March [10]. The mean maximum temperature remains high throughout the year and it's $33.5^{\circ} \mathrm{C}$ particularly in March and June [11].

The physiographic features of Minna area consist of gently undulating high plains developed on complex rocks made up of granites, migmatites, gneisses and schists [10]. Inselbergs of "Older Granites" and low hills of schists rise conspicuously above the plains [12,13]. 


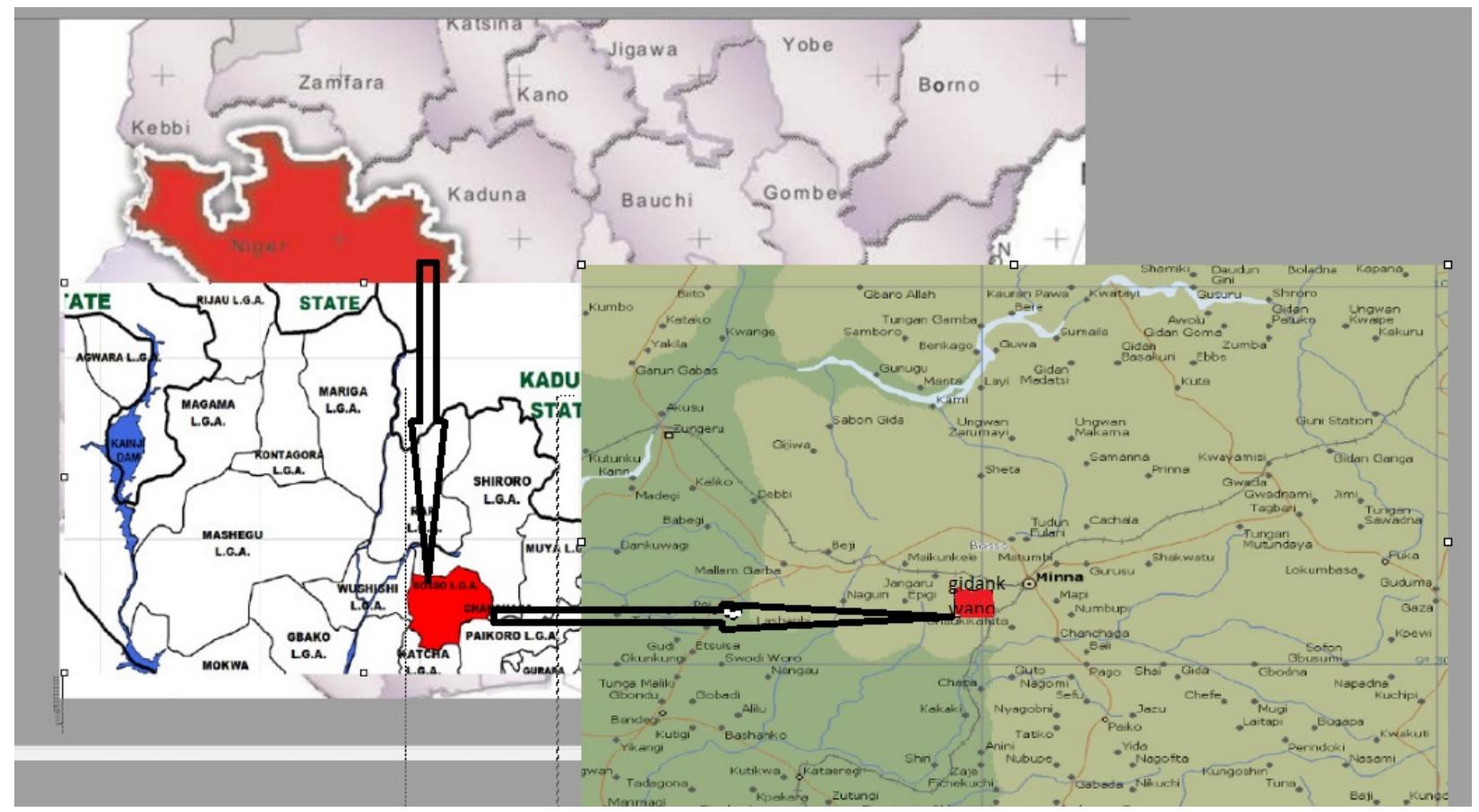

Figure 1. Map showing the study area.

\section{Topographical survey}

The topographical coordinates of the farmlands were determined with the aid of a GPS and a laptop Google application as recommended by Rosen [8]. It took place in April, 2016. Along the slope of cultivation, the coordinates and elevation of the upper end and lower end of the farmland were read and recorded. The readings were then used to determine for the slope of the farmlands.

\section{Data collection}

Four farms at different locations in Gidan Kwano were selected for the study. They include school farm, Mallam Aliyu's farm, Masohi farm and Mallam Audu's farm. They were labeled farm $\mathrm{A}, \mathrm{B}, \mathrm{C}$ and D respectively. Information was collected through oral interview and questionnaires to ensure proper understanding of information collected and accurate information because the majority of the farmers are not well-educated. 


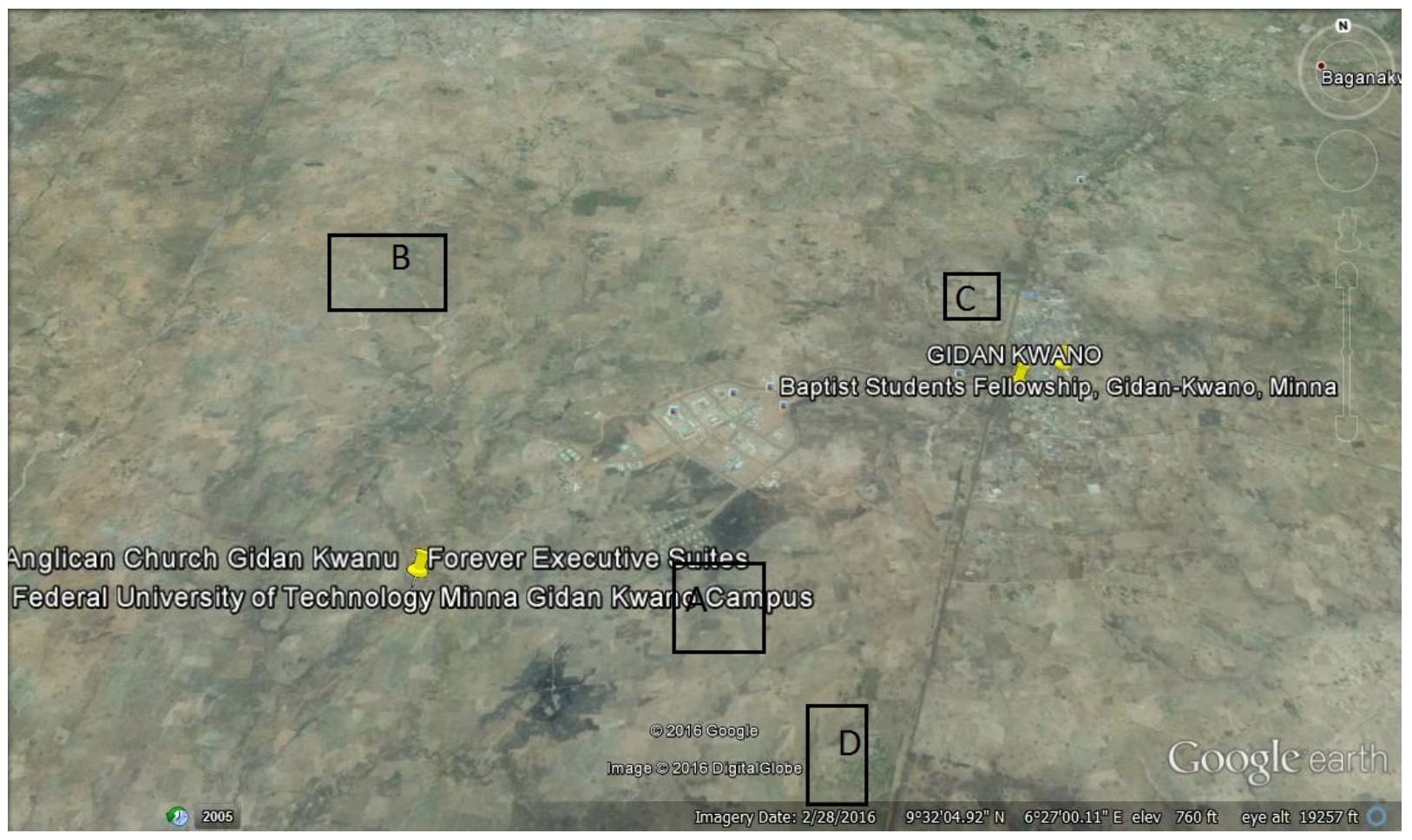

Figure 2. Map showing selected locations

\section{Soil Sampling}

Soil samples were collected from the four farm locations and selected chosen for Gidan Kwano village for study. The locations were labeled A, B, C and D respectively corresponding to different soil sample location. Three samples were randomly collected at each location on the various farmlands and a fourth was collected from any plot on the farmland with severe erosion problem as identified and observed by the farmers and during the interview session and was used as the control sample.

The sampling was done in April, 2016. The soil collection was done with the aid of a soil auger. It was driven gently $15 \mathrm{~cm}$ into the ground in each sampling location with the use of a driving rod. The collected sample in soil auger were carefully removed and emptied into a polythene bag, after which it was packed into the sampling cans for various locations to avoid escape of moisture. Approximately $1 \mathrm{~kg}$ of soil sample was collected for each location. Masking tape was made in holding the cans label in place with each signifying its location of collection. The samples collected were thereafter taken directly to the laboratory for analysis. Four core rings were used in each location for soil sample collection after using the soil auger for soil sampling. The core samplings carried out were calculated for the bulk density. The core rings were small metal with the shape of an open ended cylinder with a height of $40 \mathrm{~cm}$ and a diameter of $55 \mathrm{~cm}$ and soil collection was done as recommended by Aikins and Afuakwa (2012) [15] using the core method.

\section{Infiltration rate/Permeability}

The infiltration rate was determined using the infiltrometer method. The infiltrometer was used as a cylindrical piece of steel with a diameter of $300 \mathrm{~mm}$ and a height of $250 \mathrm{~mm}$. The bottom was sharpened for easy penetration into the soil. As described by Musa and Egharevba (2009) [16], the ring was driven into the ground by hammering a wooden bar placed diametrically on the ring to prevent any blowout effects around the bottoms of the ring. In areas where ridges and furrows existed, ring was always placed in the furrow. 


\section{Moisture Content}

The collected soil samples were collected from the sampling can with soil brought from various farm locations and was determined using the soil moisture content gravimetrically (ASABE Standards, 2008) method [17].

\section{Dry Bulk Density}

Soil dry bulk densities of the collected samples in the core ring were determined using the core method. Dry bulk densities were then calculated from the ratio of mass of dry soil per unit volume of soil cores.

$$
\text { Bulk density }=\frac{\text { Weight of dried soil- Weight of container }}{\text { Volume of core ring }} .
$$

\section{Total Porosity}

As described by Rosen (2009) [8] and Chancellor (1994) [19], the soil total porosity was calculated using values gotten from the determination of the bulk densities of the soil samples. The particle density of the soil was $2.65 \mathrm{Mgm}^{-3}[8,19]$. The results were multiplied by 100 .

$$
\text { Total porosity }(\%)=\left(\frac{1-\rho b}{\rho p}\right) \times 100 \text {, }
$$

where $\rho b=$ Dry bulk density $\left(\mathrm{Mgm}^{-3}\right)$ and $\rho p=$ Particle density $\left(\mathrm{Mgm}^{-3}\right)$.

\section{Soil Organic Matter Content}

The soil organic matter content was determined by first weighing empty crucibles to be used for the determination. The readings were recorded. Soil samples were then transferred into the small crucibles and placed inside a drying oven for about $120^{\circ} \mathrm{C}$ for 5 to $6 \mathrm{~h}$. After removing from the oven, the samples were weighed again and the values were recorded. After oven drying, equal quantity of soils for all the samples were then collected in crucibles and their weights were recorded. The new weights of the dried soils were recorded. The crucibles with the dried soils were placed into a muffle furnace and set at a temperature of about $400{ }^{\circ} \mathrm{C}$ for $4 \mathrm{~h}$. The crucibles were then removed from the muffle furnace with the aid of a tong. The soil samples were then weighed again and the reduction in weights after burning in the muffle furnace were used to express the organic matter content. The values were multiplied by 100 to express the result in percentage. The organic carbon content is usually $58 \%$ of the organic matter content as described by Doran (2012) [20].

Organic Matter Content $(\%)=\frac{\text { Weight of soil after burning in muffle furnace }- \text { Weight of soil after ovendrying }}{\text { Weight of soil after ovendrying }- \text { Weight of container }} \times$

\section{Aggregate Stability}

The aggregate stability was done as prescribed by Kemper and Rosenau (1986) [21]. The water stable aggregates can be expressed as equal to the weight of soil obtained in the dispersing solution container divided by the sum of the weights obtained in the two containers and the Mean weight diameter (MWD) can be easily determined from formula below.

$$
\sum_{i}^{n=1}(x i+W i)
$$

where $x i=$ mean (average) diameter of the proceeding and preceding sieve (upper and lower sieves) and $W i=$ proportional weight of sand free aggregates.

\section{Particle Size Analysis}

The particle size analyses of the soil samples were determined using the Bouyoucos hydrometer method. 


\section{Soil Textural Class}

The soil textural class was determined from the result of particle size analysis. The various percentages of clay, sand and silt determined from the particle size analysis was aligned on the soil textural triangle and was used to map out the soil textural class of all the collected soil samples of each farmland. Soil result analysis was done using SPSS for finding the degree of significance.

\section{Results}

The results from questionnaire showed that the sizes of the farmlands ranged between 8.5 and 15 hectares. Farming activities are mainly carried out by the males with very few exceptions to women involved in activities such as weeding, harvesting and processing of harvested farm produce. Seventy-five percentage (\%) of farmers depended on only rain-fed agriculture while the remaining twenty-five percentages (\%) depended on both irrigation and rain fed agriculture. Most of the farmers have worked with little or no soil conservation practice (mulching, cover cropping, terracing and bunding) on their farmlands. Almost all the farmers stated that the yield from the farms has been decreasing over the years and they could not explicitly attribute it to a particular factor. Erosion is considered as a major problem in all the farmlands where many cases were identified by the farmers. They all addressed that the intensity of erosion is sometimes influenced by the slope and rainfall intensity. As described by Rosen (2009) [8], the slopes were calculated from the readings of the cordinates and elevations. They were all found to be less than $3 \%$ which signifies that the topography consists of mainly flatlands and that the slope of nearly $2 \%$ as discussed by Lawal et al. (2014) [13] and Egharevba (2004) [22] were similar with the results gotten.

Table 1. Bulk density, porosity and moisture content.

\begin{tabular}{|c|c|c|c|c|c|c|c|}
\hline Farm & \multicolumn{2}{|c|}{ Bulk density $\left(\mathrm{gcm}^{-3}\right)$} & \multicolumn{2}{|c|}{ Porosity (\%) } & \multicolumn{2}{c|}{ Moisture content (\%) } \\
\hline Arosion & $\begin{array}{c}\text { Non eroded } \\
\text { field }\end{array}$ & $\begin{array}{c}\text { Erosion } \\
\text { field }\end{array}$ & $\begin{array}{c}\text { Non eroded } \\
\text { field }\end{array}$ & $\begin{array}{c}\text { Erosion } \\
\text { field }\end{array}$ & $\begin{array}{c}\text { Non eroded } \\
\text { field }\end{array}$ \\
\hline B & 1.606 & 1.521 & 39.396 & 42.603 & 11.020 & 11.280 \\
\hline C & 1.683 & 1.544 & 36.490 & 41.735 & 2.730 & 4.230 \\
\hline D & 1.475 & 1.458 & 44.340 & 44.980 & 13.570 & 19.880 \\
\hline
\end{tabular}

Table 2. Particle size Distribution, organic matter content and aggregate stability.

\begin{tabular}{|c|c|c|c|c|c|c|c|c|c|c|c|c|}
\hline Farm & \multicolumn{5}{|c|}{ Particle Size Distribution (\%) } & \multicolumn{2}{c|}{$\begin{array}{c}\text { Organic Matter } \\
\text { Content (\%) }\end{array}$} & \multicolumn{2}{|c|}{$\begin{array}{c}\text { Aggregate Stability } \\
(\%)\end{array}$} \\
\hline & \multicolumn{3}{|c|}{ Erosion } \\
field & $\begin{array}{c}\text { Non } \\
\text { eroded } \\
\text { field }\end{array}$ & \multicolumn{2}{|c|}{$\begin{array}{c}\text { Erosion } \\
\text { field }\end{array}$} & $\begin{array}{c}\text { Non } \\
\text { eroded } \\
\text { field }\end{array}$ \\
\hline & Sand & Silt & Clay & & Sand & Silt & Clay & & & & & \\
\hline A & 80.24 & 8.72 & 11.04 & 68.24 & 16.72 & 15.04 & 0.33 & 0.52 & 66.94 & 67.00 \\
\hline B & 86.24 & 4.72 & 9.04 & 76.24 & 12.72 & 11.04 & 0.29 & 0.30 & 58.00 & 63.97 \\
\hline C & 78.24 & 10.72 & 11.04 & 59.57 & 59.57 & 13.71 & 0.73 & 1.09 & 67.60 & 68.93 \\
\hline D & 82.24 & 6.72 & 13.04 & 68.91 & 68.91 & 14.37 & 0.38 & 0.83 & 67.31 & 65.17 \\
\hline
\end{tabular}


Table 3. Infiltration rate of selected plots in study location.

\begin{tabular}{|c|c|c|c|c|c|c|c|c|c|}
\hline \multirow{2}{*}{ Time (min) } & \multicolumn{3}{|c|}{$\begin{array}{c}\text { Infiltration rates on the Erosion } \\
\text { fields of the farmlands }(\mathrm{cm} / \mathrm{hr})\end{array}$} & \multicolumn{3}{|c|}{$\begin{array}{c}\text { Infiltration rates on the Non eroded } \\
\text { fields of the farmlands (cm/hr) }\end{array}$} \\
\hline & $\mathrm{A}$ & $\mathrm{B}$ & $\mathrm{C}$ & $\mathrm{D}$ & & $\mathrm{A}$ & $\mathrm{B}$ & $\mathrm{C}$ & $\mathrm{D}$ \\
\hline 0 & - & - & - & - & & - & - & - & - \\
\hline 2 & 58.85 & 49.45 & 64.85 & 58.20 & & 60.15 & 52.25 & 66.15 & 63.75 \\
\hline 4 & 57.40 & 48.15 & 60.20 & 56.35 & & 58.25 & 50.80 & 63.45 & 61.45 \\
\hline 8 & 40.55 & 41.75 & 55.75 & 50.10 & & 42.50 & 45.55 & 59.70 & 54.85 \\
\hline 12 & 37.10 & 39.05 & 50.35 & 44.05 & & 39.35 & 42.65 & 54.25 & 47.00 \\
\hline 16 & 28.70 & 32.10 & 40.75 & 40.40 & & 29.95 & 38.85 & 46.85 & 45.55 \\
\hline 20 & 26.15 & 30.60 & 36.20 & 37.85 & & 28.40 & 33.45 & 38.80 & 40.20 \\
\hline 24 & 25.35 & 27.95 & 32.95 & 31.70 & & 26.85 & 30.05 & 35.05 & 35.25 \\
\hline 28 & 20.65 & 20.35 & 29.00 & 27.45 & & 22.05 & 26.15 & 31.65 & 30.65 \\
\hline 32 & 19.85 & 19.75 & 21.65 & 21.10 & & 21.75 & 21.35 & 24.10 & 22.95 \\
\hline 36 & 18.45 & 16.25 & 19.80 & 21.05 & & 20.25 & 18.85 & 22.50 & 22.60 \\
\hline 40 & 18.30 & 16.10 & 19.55 & 19.25 & & 19.00 & 18.00 & 22.05 & 20.35 \\
\hline 60 & 17.15 & 15.45 & 18.65 & 18.05 & & 17.85 & 16.55 & 21.15 & 19.65 \\
\hline $\begin{array}{c}\text { Cumulative } \\
\text { infiltration } \\
\text { (min) }\end{array}$ & 25.26 & 24.66 & 31.04 & 29.36 & & 26.57 & 27.28 & 33.70 & 32.02 \\
\hline & & & & & & & & & \\
\hline
\end{tabular}

\section{Discussion}

\section{Infiltration rate}

The values of the cumulative infiltration rates from Table 3 were between 24.66 and $33.70 \mathrm{~cm} / \mathrm{min}$. The values from the table were higher in the samples collected from the non eroded fields than that of those collected from the erosion fields. The values were in line with works done by Musa and Egharevba (2009) [16] in which they had values like 23.69, 31.05 and $38.42 \mathrm{~cm} / \mathrm{min}$ in their infiltration study of soils in the school farm of the main campus of Federal university of technology, Minna which is very close to the study location [16]. These values generally indicated that the permeability class of the locality is rapid as discussed by Ayu et al. (2013) [14]. The higher infiltration rates of non eroded fields disclosed that erosion decreases the infiltration rate of soils by degrading the soil's structure and stability which reduces water infiltration as stated by Pimentel (2005) [1].

\section{Bulk density and Moisture Content}

The values of the bulk density from Table 3 showed that the bulk densities in the erosion fields on the farms from which samples were collected were higher than those collected from the farms where there were no erosion. The values of the bulk densities were within the range of 1.458 $\mathrm{gcm}^{-3}$ to $1.544 \mathrm{gcm}^{-3}$ for the Non eroded fields and $1.475 \mathrm{gcm}^{-3}$ to $1.606 \mathrm{gcm}^{-3}$ for the Eroded fields. These ranges of bulk densities were slightly lower than those of the previous works on a nearby study location in Gidan kwano. Bulk density values ranged between $1.6 \mathrm{gcm}^{-3}$ and $1.9 \mathrm{gcm}^{-3}$ from Lawal et al. (2014) [13] works, although Enokela and Egharevba (2012) [23] recorded a bulk density value range of $1.04 \mathrm{gcm}^{-3}$ to $1.80 \mathrm{gcm}^{-3}$. Musa and Egharevba (2009) [16] had bulk density 
value range of $1.5 \mathrm{gcm}^{-3}$ to $1.6 \mathrm{gcm}^{-3}$ which is very close to the bulk density range on Table 3 . It could be noted that the slight differences could be attributed to the differences in organic matter content and the severity of erosion which are key factors that influences bulk density [16].

The moisture contents of collected soil sample from the erosion fields seems to be slightly lower than those collected from non eroded fields although there were few cases of exception in which the values were almost the same. The moisture content values ranged between $2.73 \%$ and $13.07 \%$. Works by Musa and Egharevba (2009) [16] in the same locality showed varied results. The slight differences could be attributed to the soil properties which are easily influenced and changed over time [14].

\section{Porosity}

The porosity of the collected soil sample from the erosion field was lower than those collected from non-eroded field. This is due to the higher bulk density and lower infiltration rate as previously discussed by many workers such as Rosen (2009) [8], Jagdale and Nimbalkar (2013) [24]. etc. Results of the porosity showed that the erosion fields had lower porosity and thus lesser water holding capacity [1]. Low porosity indicates that the soils ability to store water is reduced. Porosity directly influences the water holding capacity and the permanent wilting point of plants [8].

\section{Particle Size Distribution and Soil Textural Classification}

The particle size analysis results which indicated the percentage of sand, silt and clay showed that the soil samples collected from the erosion fields had high sand and low silt content with averagely low or same clay content when compared to the soil samples collected from the noneroded fields. The soil sample for the studied locations on Figure 2 belong to sandy loam soil textural classification except one soil sample from farm B which has a textural class of loamy sand. The values ranged mostly between $68.24 \%$ and $80.24 \%$ for sand, $4.72 \%$ and $16.72 \%$ for silt and $9.04 \%$ and $15.04 \%$ for clay. The values of the analysis were similar to previous works done in the locality by Adeboye et al. (2011) [25] and Egharevba and Mustapha (2006) [26]. The slight difference may be due to variability of soil properties overtime and difference in exact location of sampling as discussed by Jagdale and Nimbalkar (2013). From these results, the soil structural class could be classified as medium which has a value of 3. This is similar to the work of Rosen (2009) [8]. As suggested by Osman (2013) [7], soils in the sandy loam class could be considered to be fertile. Since most of the soils were in that class, it indicated that soils were averagely fertile and it adjudged the information gotten from the farmers to be true.

\section{Organic Matter Content}

The organic matter content of the soil samples collected from the erosion fields were lower than those collected from the non-eroded fields. The organic matter contents ranged between $0.3 \%$ and $1.4 \%$. Previous research works carried out in this locality shows dissociate values for organic matter content. Lawal et al. (2014) [13] had organic matter contents range of $0.8 \%$ to $4 \%$ while Egharevba and Mustapha (2006) [26] had $0.09 \%$ to $0.83 \%$. This slight variability could be attributed to the temporal nature of organic matter since it is not a relatively long term property and it changes overtime depending on the soil usage and fertilization.

\section{Aggregate Stability}

The soils aggregate stability of all the farms ranged between $58 \%$ and $68.93 \%$. These values showed that the farmlands were averagely susceptible to erosion. Though this range is common to the middle belt of Nigeria (guinea savannah), it decreases with increase in the rate of erosion. The aggregate stabilities of soil samples collected from erosion fields were lower than those collected from the non-erosion fields. This claim is further supported by Pimentel (2005) [1] who stated that already degraded soil is much susceptible to erosion and eroded faster than soil under normal conditions. The aggregate stability is an indicator of soils resistance to erosion and structural damage. 


\section{Erosion effect on soil physical properties}

From the results discussed, it noted that the erosion field on farm A had a higher bulk density, low infiltration rate, organic matter content, porosity and aggregate stability when compared with the non-eroded field. This results indicated that erosion decreases with low organic matter content, porosity, agreggate stability, infiltration rate and increases the bulk density. The same effects were also observed on the soils sample collected from farm B, C and D.

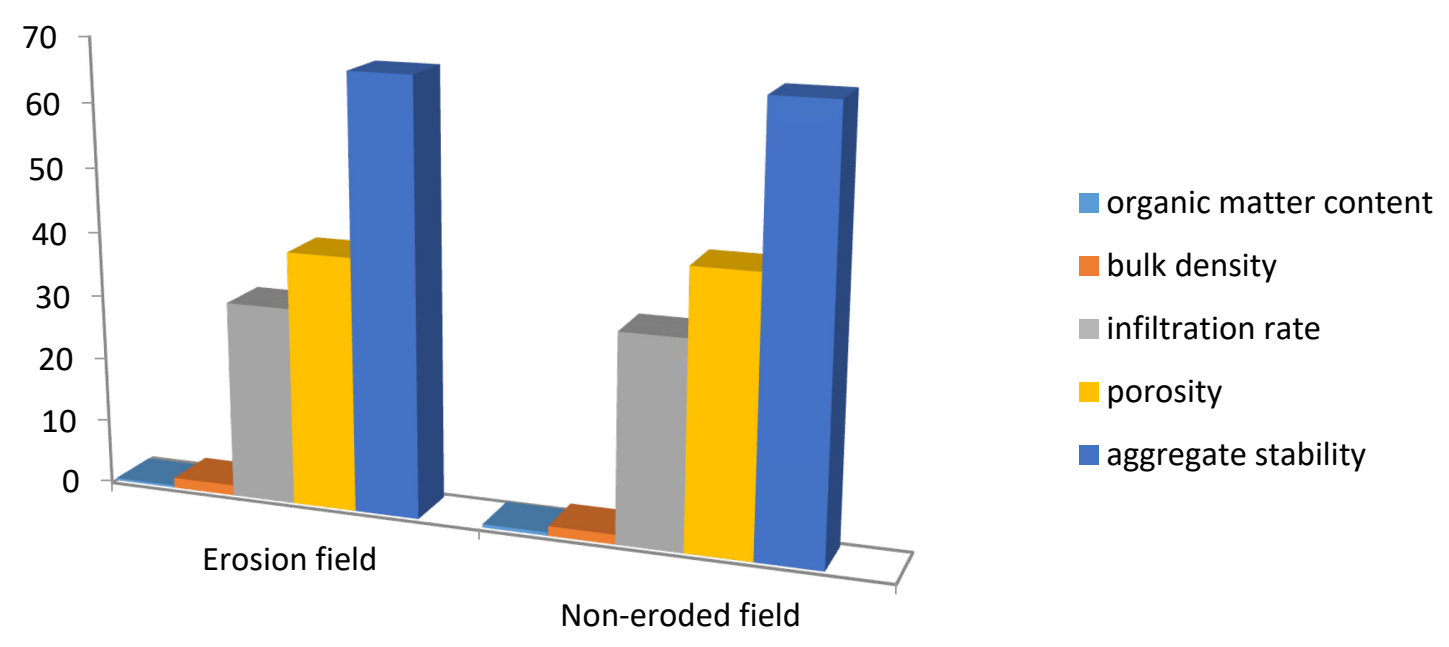

Figure 3. Erosion effect on the soil physical properties of farm A.

Notably, the farm $\mathrm{C}$ had the highest infiltration rate, organic matter content, aggregate stability, porosity and the lowest bulk density which signifies that it's the most fertile of all the farms. This could be attributed to the fact that farming activities started after a prolonged fallow period. The results also showed that soils properties such as aggregate stability, porosity, organic matter content is decreased with increased erosion action. Moisture content is not really a determining factor as it's easily influenced by many other properties and factor [14]. Bulk density increased with increased erosion which may be due to the compacted nature of the erosion field as discussed by Pimentel (2005) [1].

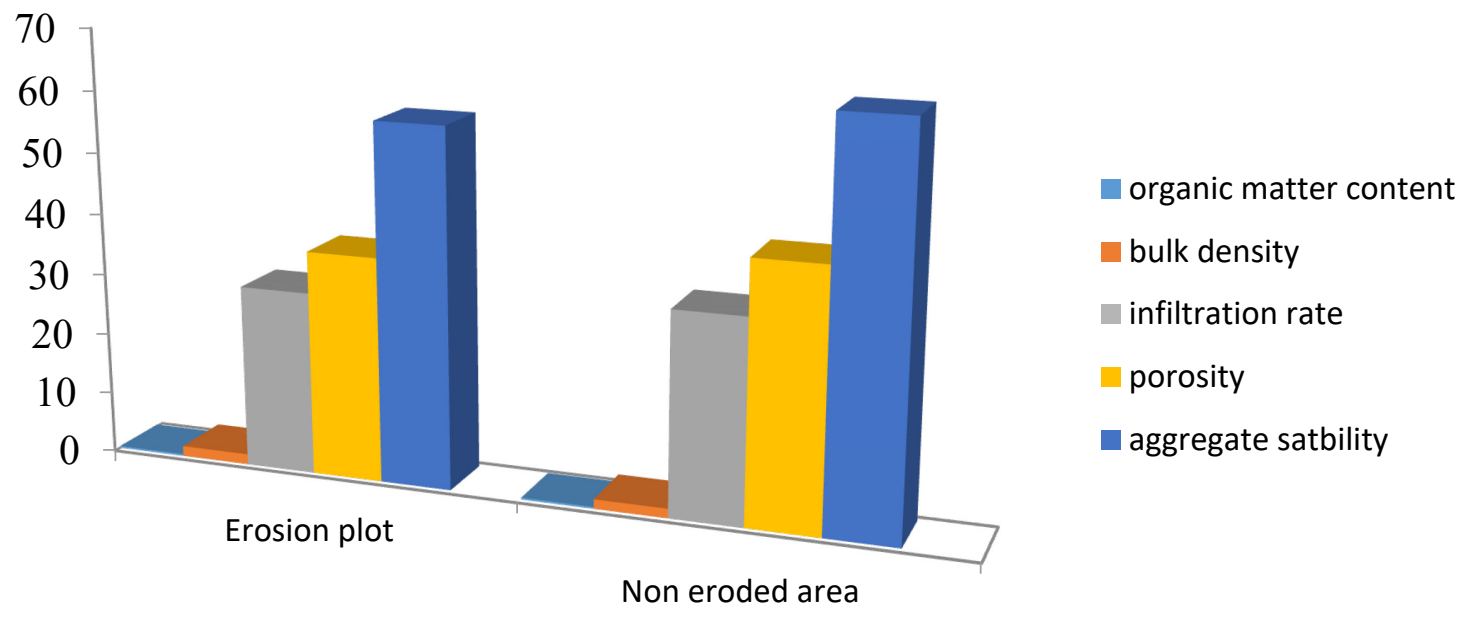

Figure 4. Erosion effect on the soil physical properties of farm B.

Statistical analysis done showed that there were no statistical significant differences $(\mathrm{P}>0.05)$ in the results of bulk density, porosity and moisture content between eroded and non-eroded fields while there were significant differences $(\mathrm{P}<0.05)$ in the organic matter content, aggregate stability, infiltration rate and percentage of sand, silt and clay. 


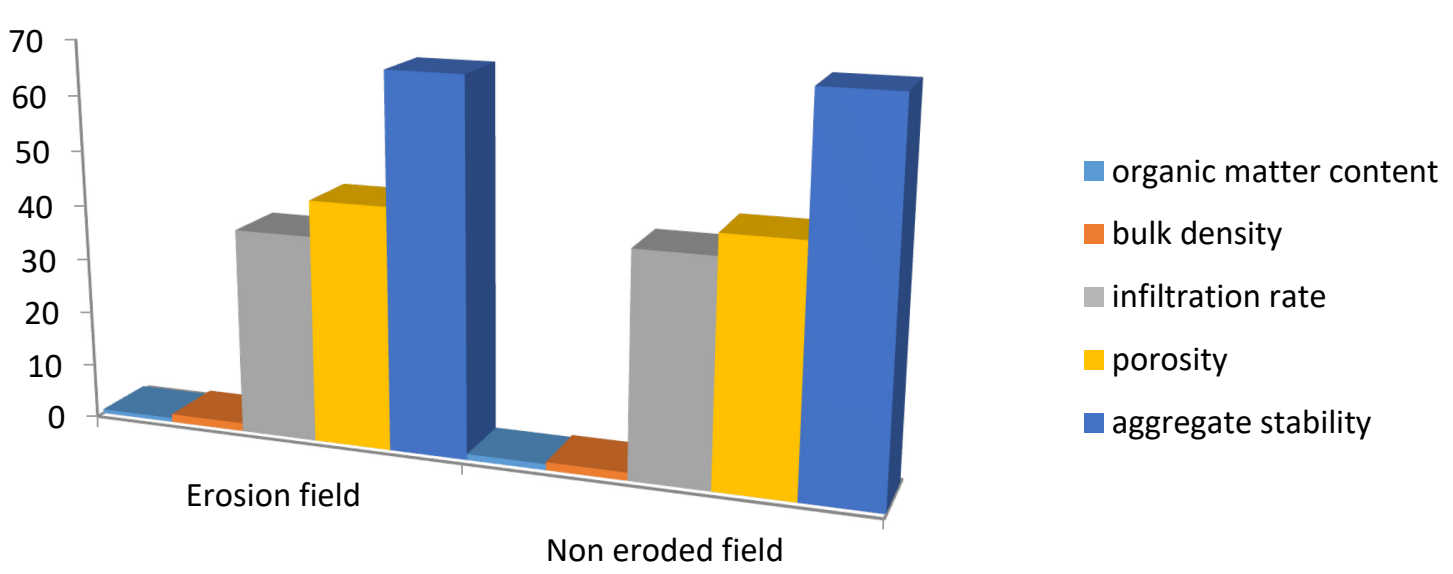

Figure 5. Erosion effect on the soil physical properties of farm C.

This is similar to the work of Rosen (2009) [8]. The reasons for the insignificances could be attributed to the bulk density, porosity and moisture content which are dependent on factors such as compaction and swelling characteristics of the soil. They are easily altered and influenced by human and biological activities and interactions.

Results of the physical properties such as organic matter content, structure stability, texture and infiltration rate were used as described by Adam Kertesz (2004) [27] to determine the soil erodibility factor which gave values ranging between 0.1426 and 0.1436 which could be said to be $0.143 \pm 0.002$ for all the soil samples. The Nomogram was

$$
\mathrm{k}=\left(2.77 * 10^{-6 *} \mathrm{M}^{1.14}(12-\mathrm{OS})+0.043(\mathrm{~A}-2)+(0.033)(4-\mathrm{D})\right) \text {, }
$$

where $\mathrm{k}=$ erodibility factor, $\mathrm{M}=\%$ fine material, $\mathrm{A}=$ aggregate class, $\mathrm{OS}=$ organic matter content $(\%)$ and $\mathrm{D}=$ permeability Class. These showed the level of susceptibility of the soils to erosion.

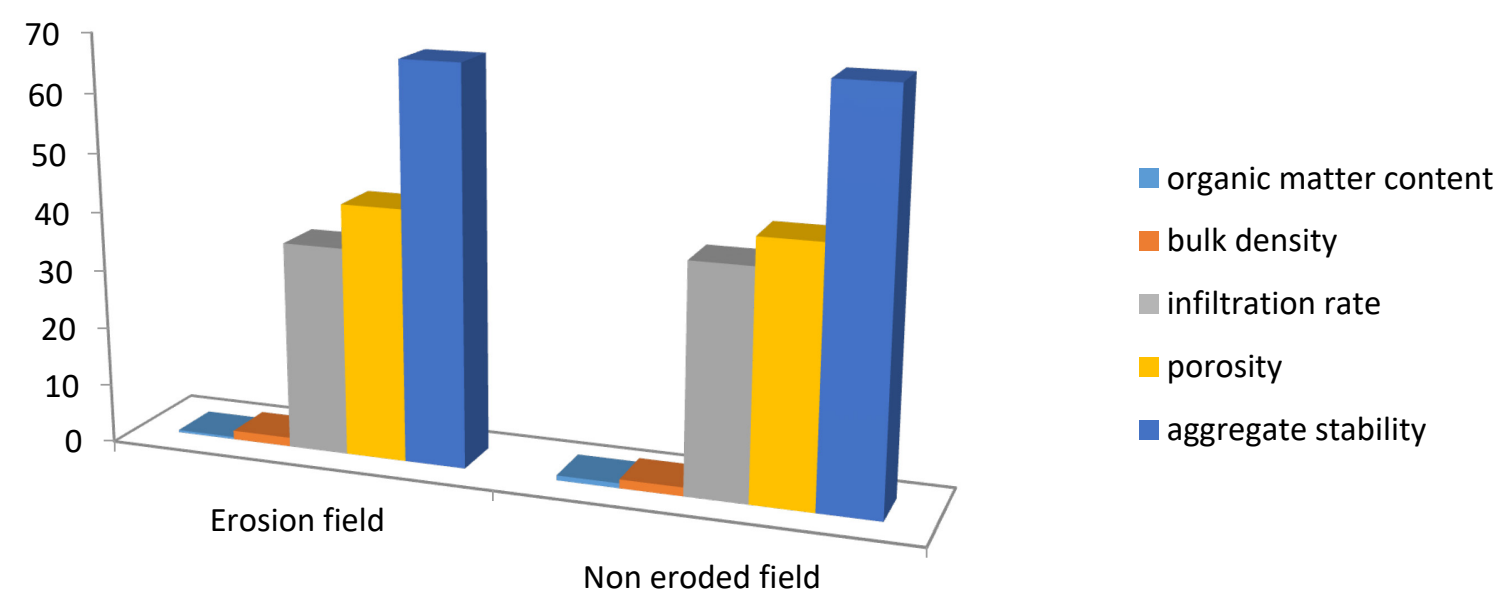

Figure 6. Erosion effect on the soil physical properties of farm D. 


\section{Analysis}

Table 4. Statistical analysis(correlation).

\begin{tabular}{|c|c|c|c|c|}
\hline $\begin{array}{c}\text { Paired Samples } \\
\text { correlations }\end{array}$ & $\begin{array}{c}\text { Physical properties } \\
\text { Eroded ----------non eroded }\end{array}$ & N & Correlation & Significance \\
\hline Pair 1 & $\begin{array}{c}\text { eroded sample infiltration rate - non } \\
\text { eroded sample infiltration rate }\end{array}$ & 4 & .984 & .016 \\
\hline Pair 2 & $\begin{array}{c}\text { eroded sample bulk density - non eroded } \\
\text { sample bulk density }\end{array}$ & 4 & .947 & .053 \\
\hline Pair 3 & $\begin{array}{c}\text { eroded sample \%porosity - non eroded } \\
\text { sample \%porosity }\end{array}$ & 4 & .944 & .056 \\
\hline Pair 4 & $\begin{array}{c}\text { eroded sample \%moisture content - non } \\
\text { eroded sample \%moisture content }\end{array}$ & 4 & .873 & .127 \\
\hline Pair 5 & $\begin{array}{c}\text { eroded sample \%aggregate stability - non } \\
\text { eroded sample \%aggregate stability }\end{array}$ & 4 & .905 & .095 \\
\hline Pair 6 & $\begin{array}{c}\text { eroded sample \%sand - non eroded } \\
\text { sample \%sand }\end{array}$ & 4 & .954 & .046 \\
\hline Pair 7 & $\begin{array}{c}\text { eroded sample\% silt - non eroded sample } \\
\text { \%silt }\end{array}$ & 4 & .908 & .092 \\
\hline Pair 8 & $\begin{array}{c}\text { eroded sample \%clay - non eroded sample } \\
\text { \%clay }\end{array}$ & 4 & .776 & .224 \\
\hline Pair 9 & $\begin{array}{c}\text { eroded sample \%organic matter content - } \\
\text { non eroded sample \%organic matter } \\
\text { content }\end{array}$ & 4 & .911 & .089 \\
\hline
\end{tabular}

Table 5. Statistical analysis (test).

\begin{tabular}{|c|c|c|c|c|c|c|c|c|c|}
\hline $\begin{array}{l}\text { Paired } \\
\text { Samp- } \\
\text { les } \\
\text { Test } \\
\end{array}$ & $\begin{array}{l}\text { Physical properties } \\
\text { Eroded -non eroded }\end{array}$ & Mean & $\begin{array}{c}\text { Std. } \\
\text { deviation }\end{array}$ & $\begin{array}{l}\text { Std. } \\
\text { error } \\
\text { mean }\end{array}$ & \multicolumn{2}{|c|}{$\begin{array}{l}95 \% \text { Confidence } \\
\text { Interval of the } \\
\text { Difference }\end{array}$} & $\mathrm{t}$ & d.f. & Sig. \\
\hline & & & & & lower & upper & & & \\
\hline Pair 1 & $\begin{array}{l}\text { eroded sample } \\
\text { infiltration rate - non } \\
\text { eroded sample } \\
\text { infiltration rate } \\
\end{array}$ & $-2.7125000 \mathrm{E} 0$ & .8204216 & .4102108 & -4.0179739 & -1.4070261 & -6.612 & 3 & .007 \\
\hline Pair 2 & $\begin{array}{l}\text { eroded sample bulk } \\
\text { density - non eroded } \\
\text { sample bulk density }\end{array}$ & $6.3500000 \mathrm{E}-2$ & .0602080 & .0301040 & -.0323043 & .1593043 & 2.109 & 3 & .125 \\
\hline Pair 3 & \begin{tabular}{|c|} 
eroded sample \\
\%porosity - non eroded \\
sample \%porosity
\end{tabular} & $-2.6455000 \mathrm{E} 0$ & \begin{tabular}{|l|}
2.4402113 \\
\end{tabular} & 1.2201056 & -6.5284207 & 1.2374207 & -2.168 & & .119 \\
\hline Pair 4 & $\begin{array}{l}\text { eroded sample } \\
\% \text { moisture content - } \\
\text { non eroded sample } \\
\% \text { moisture content }\end{array}$ & $\mid-3.6500000 \mathrm{E} 0$ & \begin{tabular}{|l|}
3.2395782 \\
\end{tabular} & 1.6197891 & -8.8048918 & 1.5048918 & -2.253 & 3 & .110 \\
\hline Pair 5 & \begin{tabular}{|c|} 
eroded sample \\
\%aggregate stability - \\
non eroded sample \\
\%aggregate stability
\end{tabular} & \begin{tabular}{|l|}
$-1.3905000 \mathrm{E} 1$ \\
\end{tabular} & 3.6221403 & 1.8110701 & -19.6686334 & -8.1413666 & -7.678 & 3 & .005 \\
\hline Pair 6 & $\begin{array}{c}\text { eroded sample \%sand - } \\
\text { non eroded sample } \\
\% \text { sand }\end{array}$ & $1.3500000 \mathrm{E} 1$ & \begin{tabular}{|l|}
3.7084498 \\
\end{tabular} & 1.8542249 & 7.5990288 & 19.4009712 & 7.281 & 3 & .005 \\
\hline Pair 7 & $\begin{array}{c}\text { eroded sample } \% \text { silt - } \\
\text { non eroded sample } \\
\% \text { silt }\end{array}$ & $\mid-1.0500000 \mathrm{E} 1$ & \begin{tabular}{|l|}
3.7859389 \\
\end{tabular} & 1.8929694 & -16.5242736 & -4.4757264 & -5.547 & 3 & .12 \\
\hline Pair 8 & $\begin{array}{c}\text { eroded sample \%clay - } \\
\text { non eroded sample } \\
\% \text { clay }\end{array}$ & $\mid-2.5000000 \mathrm{E} 0$ & 1.1398538 & .5699269 & -4.3137617 & -.6862383 & -4.387 & 3 & .22 \\
\hline Pair 9 & $\begin{array}{c}\text { eroded sample } \\
\text { \%organic matter } \\
\text { content - non eroded } \\
\text { sample \%organic } \\
\text { matter content }\end{array}$ & $-3.3000000 \mathrm{E}-1$ & .1169045 & .0584523 & -.5160212 & -.1439788 & -5.646 & 3 & .11 \\
\hline
\end{tabular}


Statistical analysis done shows that erosion has effect on the physical properties and the result was significant $(\mathrm{p}<0.05)$ except for the bulk density and porosity which could be attributed to the swelling and compaction characteristics of the soils.

\section{Conclusions}

The result of the study indicated that Gidan kwano is a relatively small settlement of which farming is their major occupation. They practiced both subsistence and commercial agriculture. Cultivation was mainly season-dependent since they mostly practice rain fed agriculture. Erosion was found to be a relatively major problem in the locality. Soil conservation practice and land management practice were not taken as a priority.

The results showed that erosion fields on the farms had lower organic matter content, lower aggregate stability, higher bulk density, lower infiltration rate and porosity when compared with the non-eroded fields. It indicates that the effect of erosion on the selected soil physical properties had negative consequences on those properties and tends to decrease the soil fertility and productivity. Based on the results of the analysis carried out, it is evident that erosion affects the infiltration rate, organic matter content, aggregate stability, bulk density and porosity of soils.

\section{Conflict of interest}

I declare that there is no conflict of interest.

\section{References}

[1] D. Pimentel, Soil erosion: a food and environmental threat. Environment, Development and Sustainability. 8 (2005) 119-136.

[2] P.M. Farmanullah, Erosion and its danger, Special Publication of the Soil Science Society of America. 48 (2013) 7-29.

[3] J.L. Pardo, I.P. Warder, E.M. Qout, Food and environmental threat, Environment, Development and Sustainability. 8 (2002)119-137.

[4] A. McCauley, J. Clain, J. Jeff, Basic soil properties, Development and Sustainability. 9 (2005) 114-123.

[5] N.C. Brady, R.R. Weil, Raising and sustaining productivity of small farming system in the tropics, Agbe Publishers, 13th Edition, Alkmaar, Netherlands, 2002, pp. 175-291.

[6] P. Louis, Erosion Impacts on Soil and Environmental Quality, Vertisols in the Highlands Region of Ethiopia, M.Sc. Dissertation, University of Nairobi, 2011.

[7] K.T. Osman, Forest soils, Journal of tropical agricultural resources. 13 (2013) 143-154.

[8] S. Rosen, Soil physical properties and erosion risk at smallholder farms in Embu, Kenya, Undergraduate Thesis, 2009, pp. 4-7.

[9] D.D. Fangmeier, et al., Soil and Water Conservation Engineering, Thomson Delmar Learning, New York, 2006, pp. 34-48.

[10] J.O. Afolabi et al., Evaluation of some soils of Minna southern guinea savanna of Nigeria for arable crop production, Nigerian Journal of Agriculture, Food and Environment. 10(4) (2014) 6-9.

[11] A. J. Ojanuga, Agroecological zones of Nigeria Manual, F.A.O. /N.S.P.F.S., Federal Ministry of Agriculture and Rural Development, Abuja, Nigeria, 2006. 
[12] M.K.A. Adeboye et al., Evaluation of the fertility status and suitability of some soils for arable cropping in the southern guinea savanna of Nigeria, Nigerian Journal of Soil Science. 19(2) (2009) 115-120.

[13] B.A. Lawal et al., Properties, classification and agricultural potentials of lateritic soils of Minna in sub-humid agroecological zone in Nigeria, International Journal of Development and Sustainability. 1(3) (2014) 903-911.

[14] W.I. Ayu, P. Sugeng, D. Soemarno, Assessment of infiltration rate under different drylands types in unter-iwes subdistrict Sumawa Besar in Indonesia, Journal of Natural Sciences Research. 12 (2012)154-163.

[15] H. Aikins, K.P. Afuakwa, Effect of residue placement and chemical fertilizer on soil microbial biomass under tropical dryland cultivation, Boilogy and Fertility of Soils. 16 (2012) 275-281.

[16] J. Musa, N. Egharevba, Soil grouping of the Federal University of Technology, Minna, Main Campus Farm Using Infiltration Rate, A.U. J.T. 13(1) (2009)19-28.

[17] J. Carter, Soil Sampling and Methods of Analysis, 2nd Edition, C. R. C. Press, Boca Raton, FL., USA, 2002.

[18] D.W. Chancellor, The role of soil organic manure in maintaining soil quality in continuous cropping systems, Soil Tillage Research. 43 (1994) 131-167

[19] J.W. Doran, Defining and assessing soil quality, Special Publication of the Soil Science Society of America. 35 (2012) 3-21.

[20] W.D. Kemper et al., Aggregate soil stability, Trans. A.S.A.E. 28 (1986) 1564-1572.

[21] N.A. Egharevba, Evaluation of sediment yield from agricultural fields during natural rainfall events, Journal of Sustainability of Tropical Agricultural Resources. 11 (2004) 104-108.

[22] E. Enokela, N. Egharevba, Measurement of the productivity of soils under various environmental conditions, Journal of Agronomy. 42 (2012) 282-292.

[23] S.D. Jagdale, P.T. Nimbalkar, Infiltration studies of different soils under different soil conditions and comparison of infiltration models with field data, Journal of Irrigation and Drainage Engineering. 11 (2013) 202-212.

[24] M.A. Adeboye, Some physicochemical characteristics of soil of basement complex adjoining basaltic rocks of northern part of Nigeria, in: The Proceeding of the 15th Annual Conference of Soil Science Society of Nigeria, 2011, pp. 205-214.

[25] N.A. Egharevba, H.I. Mustapha, Prediction of Sediment Yield in Runoff from Agricultural Land in the Southern Guinea Savanna Zone of Nigeria, Development and Sustainability. 42 (2006) 98-112.

[26] A.M Kertesz, B.G. Ritcher, Assessment of soil erosion in small water shed covered by loess, Geojournal. 6(2) (2004) 285-288 